\title{
GAMBARAN KINERJA KEPALA RUANGAN DAN KETUA TIM DI RUANG MODEL PRAKTIK KEPERAWATAN PROFESIONAL (MPKP) RUMAH SAKIT JIWA DAERAH PROVINSI JAMBI
}

\author{
Nini Afriani $1^{*}$, Nofrida Saswati ${ }^{2}$, Rian Maylina Sari ${ }^{3}$ \\ ${ }^{1,2,3}$ Program Studi Ilmu Keperawatan, STIKES Harapan Ibu, Jambi, Indonesia \\ Email korespondensi : niniafriani214@gmail.com
}

\begin{abstract}
DESCRIPTION OF THE PERFORMANCE OF THE HEAD OF THE ROOM AND TEAM HEAD IN THE MODEL ROOM OF PROFESSIONAL NURSING PRACTICE (MPKP) A REGIONAL MENTAL HOSPITAL OF JAMBI PROVINCE
\end{abstract}

Background The Model of Professional Nursing Practice (MPKP) has been implemented in several countries, including in various Indonesian asylums. Jambi Provincial Mental Hospital has implemented a Model of Professional Nursing Practice (MPKP), but its implementation has not been implemented in its entirety. The role and function of the head of the room and the head of the team is critical to the development of the performance of the implementing nurses in the space that has implemented the MPKP. This research aims to find out the picture of the performance of the head of the room and the team leader in the Model Room of Professional Nursing Practice (MPKP) of Jambi Provincial Psychiatric Hospital year 2020.

Method This research is quantitative research. This research was conducted in the MPKP room of Jambi Provincial Psychiatric Hospital conducted on March 26 - April 6, 2020. The population in this study was the entire head of the room as many as 10 people and and the team leader as many as 20 people in the MPKP room at jambi provincial asylum in March-April 2020. The sample in this study was as many as 30 people with total sampling techniques. Data collection is done by interviewing and filling out questionnaires. Data analyzed univariately.

Result The results of this study showed that the head of the room had a good performance and was less good each as much as 5 (50\%) Respondents. The team leader had a good performance and was underperforming by 10 (50\%) each Respondents.

Conclusion The results of this study show that both the head of the room and the team leader have not been optimal performance. It is recommended that the hospital conduct training and training in the form of workshops and seminars to increase the knowledge of the head of the room and the head of the team to implement 4 pillars of MPKP.

Keywords : Performance, Katim, Karu, MPKP 
INTISARI : GAMBARAN KINERJA KEPALA RUANGAN DAN KETUA TIM DI RUANG MODEL PRAKTIK KEPERAWATAN PROFESIONAL (MPKP) RUMAH SAKIT JIWA DAERAH PROVINSI JAMBI

Latar Belakang Model Praktek Keperawatan Profesional (MPKP) telah dilaksanakan dibeberapa negara, termasuk di berbagai rumah sakit jiwa Indonesia. Rumah Sakit Jiwa Daerah Provinsi Jambi telah menerapkan Model Praktek Keperawatan Profesional (MPKP), namun pelaksanaannya belum secara keseluruhan. Peran dan fungsi kepala ruangan dan ketua tim sangat penting untuk perkembangan kinerja perawat pelaksana pada ruang yang telah menerapkan MPKP. Penelitian ini bertujuan untuk mengetahui gambaran kinerja kepala ruangan dan ketua tim di Ruang Model Praktik Keperawatan Profesional (MPKP) Rumah Sakit Jiwa Daerah Provinsi Jambi Tahun 2020.

Metode Penelitian ini adalah penelitian kuantitatif. Penelitian ini dilakukan di ruang MPKP Rumah Sakit Jiwa Daerah Provinsi Jambi yang dilakukan pada tanggal 26 Maret - 6 April 2020. Populasi dalam penelitian ini adalah seluruh kepala ruangan sebanyak 10 orang dan dan ketua tim sebanyak 20 orang di ruang MPKP di Rumah Sakit Jiwa Daerah Provinsi Jambi pada bulan Maret-April 2020. Sampel dalam penelitian ini sebanyak 30 orang dengan teknik total sampling. Pengumpulan data dilakukan dengan wawancara dan pengisian kuesioner. Data dianalisis secara univariat.

Hasil Hasil penelitian ini menunjukkan bahwa kepala ruangan memiliki kinerja yang baik dan kurang baik masing-masing sebanyak 5 (50\%) responden.Ketua tim memiliki kinerja yang baik dan kurang baik masing-masing sebanyak $10(50 \%)$ responden.

Kesimpulan Hasil penelitian ini menunjukkan bahwa baik kepala ruangan dan ketua tim memiliki kinerja yang belum optimal. Sebaiknya rumah sakit mengadakan pelatihan dan diklat dalam bentuk workshop dan seminar agar menambah pengetahuan kepala ruangan dan ketua tim untuk menerapkan 4 pilar MPKP.

Kata Kunci: Kinerja, Katim, Karu, MPKP

\section{PENDAHULUAN}

Asuhan keperawatan merupakan titik sentral dalam pelayanan keperawatan. Manajemen asuhan keperawatan yang benar akan meningkatkan mutu pelayanan asuhan keperawatan yang bertujuan untuk memandirikan pasien sehingga dapat berfungsi secara optimal. Dalam mencapai kondisi tersebut diperlukan manajemen asuhan keperawatan yang profesional dan salah satu faktor yang menentukan dalam manajemen tersebut adalah bagaimana asuhan keperawatan diberikan oleh perawat melalui berbagai pendekatan model asuhan keperawatan yang diberikan
(Nursalam, 2015). Manajemen asuhan keperawatan profesional merupakan bagian integral yang tidak dapat dipisahkan dari upaya pelayanan kesehatan secara keseluruhan, hal ini dikarenakan sebagai salah satu faktor penentu baik buruknya mutu dan citra rumah sakit sehingga kualitas pelayanan asuhan keperawatan perlu dipertahankan serta ditingkatkan seoptimal mungkin (Kemenkes RI, 2011).

Manajemen asuhan keperawatan merupakan suatu proses kerja sama anggota staf keperawatan untuk memberikan asuhan, terapi dan bantuan kepada para pasien. 
Manajemen merupakan proses dalam menyelesaikan pekerjaan melalui orang lain. Manajemen diperlukan agar mencapai tujuan organisasi yang telah ditetapkan dalam mengatasi masalah kesehatan jiwa (Keliat, Model Praktik Keperawatan Profesional Jiwa, 2015).

Masalah kesehatan jiwa yang mendapatkan penanganan secara cepat dan tepat memungkinkan hasil yang baik. Kemenkes RI menetapkan tatanan pelayanan kesehatan jiwa dalam bentuk piramida. Piramida pelayanan kesehatan jiwa tersebut menjabarkan pelayanan kesehatan jiwa bersifat berkesinambungan dari komunitas ke rumah sakit dan sebaliknya. Pelayanan kesehatan jiwa dimulai dimasrayakat dalam bentuk pelayanan mandiri oleh klien dan keluarganya. Pelayanan lanjutan berikutnya adalah di puskesmas, rumah sakit umum, dan yang paling tinggi adalah pelayanan di rumah sakit jiwa sebagai pelayanan rujukan tertinggi untuk kesehatan jiwa. Tatanan pelayanan kesehatan jiwa di masyarakat telah dikembangkan dengan baik, namun untuk hasil yang lebih baik, maka perlu pengembangan pelayanan prima yang profesional melalui pendekatan model praktik keperawatan profesional (MPKP) (Keliat, Model Praktik Keperawatan Profesional Jiwa , 2014).

Model Praktek Keperawatan Profesional (MPKP) adalah suatu sistem (Struktur, Proses dan nilai-nilai profesional) yang memungkinkan perawat profesional mengatur pemberian asuhan keperawatan termasuk lingkungan, yang dapat menopang pemberian asuhan tersebut (Murwani \& Herlambang, 2012). MPKP adalah suatu sistem yang memfasilitasi perawat profesional, mengatur pemberian asuhan keperawatan, termasuk lingkungan tempat asuhan tersebut diberikan (Sitorus, 2014).

Model Praktek Keperawatan Profesional (MPKP) telah dilaksanakan dibeberapa negara, termasuk di berbagai rumah sakit jiwa Indonesia. MPKP telah dikembangkan dengan memodifikasi MPKP yang telah dikembangkan di rumah sakit umum. Bentuk MPKP yang dikembangkan adalah MPKP transisi dan MPKP pemula. Hasil penerapan MPKP menunjukkan peningkatan BOR, penurunan ALOS dan penurunan angka lari klien dan menunjukkan bahwa pelayanan kesehatan jiwa yang diberikan bermutu baik (Keliat, Model Praktik Keperawatan Profesional Jiwa , 2014).

Rumah Sakit Jiwa Daerah Provinsi Jambi telah menerapkan Model Praktek Keperawatan Profesional (MPKP), namun pelaksanaannya belum secara keseluruhan. Ada 10 dari 17 ruang di Rumah Sakit Jiwa Daerah Provinsi Jambi yang baru menerapkan MPKP yang terbagi menjadi MPKP Pemula, MPKP Transisi dan Profesional (Rumah Sakit Jiwa Daerah Provinsi Jambi, 2020).

Pendekatan dalam bentuk MPKP ini merupakan pendekatan proses manajemen yang meliputi struktur, proses dan nilai profesional melalui fungsi-fungsi manajemen yaitu; perencanaan, pengorganisasian, pengarahan dan pengawasan yang terintegrasi guna merealisasikan tujuan keperawatan yang ditetapkan (Nursalam, 2015).

Pengembangan model keperawatan profesional dilaksanakan dalam bentuk Model Praktik Keperawatan Profesional (MPKP). MPKP Jiwa terdiri dari empat pilar nilai profesional yaitu management 
approach, compensatoryreward, professional relationship, dan patient care delivery. Dalam pelaksanaannya dibutuhkan peran kepala ruang dan ketua tim sebagai pengelola ruang rawat namun juga berhubungan langsung dengan pasien (Keliat, Model Praktik Keperawatan Profesional Jiwa , 2014).

Peran dan fungsi kepala ruangan dan ketua tim sangat penting untuk perkembangan kinerja perawat pelaksana pada ruang yang telah menerapkan MPKP. Kinerja adalah hasil evaluasi terhadap pekerjaan yang telah dilakukan dibandingkan dengan kriteria yang telah ditetapkan bersama. Kinerja merupakan cara perseorangan atau kelompok dari suatu organisasi menyelesaikan suatu pekerjaan atau tugas (Rismawati, 2011). Evaluasi kinerja dimaksudkan sebagai umpan balik kepada karyawan mengenai pandangan organisasi terhadap kinerja karyawan, sebagai dasar untuk alokasi ganjaran (upah) dan menetapkan keputusan (Rivai \& Mulyadi, 2010).

Adapun kinerja kepala ruangan dalam 4 pilar MPKP terdiri dari pendekatan manajemen (perencanaan, pengorganisasian, pengarahan dan pengendalian), kompensasi dan penghargaan (evaluasi kinerja perawat dan pengembangan perawat). Hubungan profesional (rapat keperawatan, case conference, rapat tim kesehatan dan visit dokter) dan pemberian asuhan keperawatan (Keliat, Model Praktik Keperawatan Profesional Jiwa, 2015).

Sedangkan menurut Keliat (2014), kinerja ketua tim dalam 4 pilar yaitu pendekatan manajemen (perencanaan, pengorganisasian dan pengarahan), kompensasi dan penghargaan (evaluasi kinerja perawat), hubungan profesional (case conference dan visit dokter) dan pemberian asuhan keperawatan.

Berdasarkan data yang diperoleh dari Rumah Sakit Jiwa Daerah Provinsi Jambi, diketahui jumlah pegawai di masing-masing ruang MPKP diketahui jumlah kepala ruangan di ruang MPKP sebanyak 10 orang, jumlah ketua tim sebanyak 20 orang dan jumlah perawat pelaksana sebanyak 80 orang.

Penelitian yang dilakukan oleh (Rahayu, 2017) menunjukkan bahwa kemampuan karu dan katim dalam pendekatan manajemen dan pemberian layanan rawat inap mempunyai hubungan yang signifikan dengan pengurangan tanda dan gejala pasien $(p<0,05)$. Hasil studi ini direkomendasikan sebagai dasar untuk meningkatkan MPKP. Menurut penelitian (Mulyaningsih, 2013) berdasarkan hasil audit asuhan keperawatan di salah satu ruangan RSJD Surakarta didapatkan nilai rata-rata $85 \%$ (baik). Nilai dokumentasi yang paling rendah terdapat pada evaluasi (50\%). Hal ini menunjukkan bahwa kinerja perawat masih kurang.

Survei awal yang dilakukan oleh peneliti pada tanggal 4 Februari 2020 terhadap 2 kepala ruangan di ruang Epsilon dan Pega MPKP Rumah Sakit Jiwa Daerah Provinsi Jambi, diketahui bahwa kepala ruangan menyatakan bahwa pada ruang Epsilon telah menerapkan MPKP Profesional dan pada ruang Pega menerapkan MPKP Pemula. Kedua kepala ruangan mengatakan bahwa manajemen MPKP yang telah diterapkan berdasarkan 4 pilar MPKP yaitu pendekatan manajemen, sistem penghargaan, hubungan profesional dan manajemen asuhan keperawatan. Dalam pendekatan manajemen, kepala ruangan Epsilon telah melakukan 
perencanaan, pengarahan, pengorganisasian dan pengendalian, melakukan sistem penghargaan dengan evaluasi kinerja dan pengembangan perawat, melakukan hubungan profesional mulai dari rapat keperawatan, rapat tim kesehatan dan visit dokter. Sedangkan kepala ruangan Pega mengatakan, 4 pilar MPKP telah diterapkan hanya saja masih membutuhkan arahan dan pelatihan dari ruang MPKP profesional dalam pelaksanaannya dikarenakan belum memahami 4 pilar MPKP secara optimal. Kedua kepala ruangan mengatakan bahwa dari 4 pilar MPKP tersebut ada beberapa bagian yang tidak dikerjakan yaitu filosofi, audit, survei kepuasan, case conference, supervisi dan pemberian asuhan keperawatan kepada pasien gangguan jiwa.

\section{Wawancara kepada ketua tim} Epsilon mengatakan bahwa pada penerapan 4 pilar MPKP yaitu pendekatan manajemen, sistem penghargaan, hubungan profesional dan manajemen asuhan keperawatan telah terlaksana secara optimal dikarenakan kepala ruangan memberikan bimbingan selama ketua tim menerapkan 4 pilar MPKP tersebut. Sedangkan pada ruang Pega, ketua tim mengatakan masih perlu banyak belajar dan mengikuti pelatihan agar terbiasa menerapkan 4 pilar MPKP pada setiap ruangan. Dapat disimpulkan bahwa karu dan katim yang ada diruang Pega dengan penerapan MPKP pemula belum memahami secara mendalam penerapan 4 pilar MPKP Jiwa dan memerlukan pelatihan serta arahan untuk penerapan 4 pilar MPKP yang lebih optimal. Kedua ketua tim mengatakan bahwa pada bagian daftar pasien, evaluasi kinerja, postconference, case conference dan pemberian asuhan keperawatan tidak dikerjakan serta supervisi kadangkadang dilakukan (Rumah Sakit Jiwa Daerah Provinsi Jambi, 2020).

Berdasarkan uraian diatas, maka penulis tertarik untuk meneliti tentang "gambaran kinerja kepala ruangan dan ketua tim di Ruang Model Praktik Keperawatan Profesional (MPKP) Rumah Sakit Jiwa Daerah Provinsi Jambi Tahun 2020".

\section{METODE}

Desain pada penelitian adalah penelitian kuantitatif yang bertujuan untuk mengetahui gambaran kinerja kepala ruangan dan ketua tim di Ruang Model Praktik Keperawatan Profesional (MPKP) Rumah Sakit Jiwa Daerah Provinsi Jambi Tahun 2020. Penelitian ini dilakukan di ruang MPKP Rumah Sakit Jiwa Daerah Provinsi Jambi yang dilakukan pada tanggal 26 Maret - 6 April 2020. Populasi dalam penelitian ini adalah seluruh kepala ruangan sebanyak 10 orang dan dan ketua tim sebanyak 20 orang di ruang MPKP di Rumah Sakit Jiwa Daerah Provinsi Jambi pada bulan Maret-April 2020. Sampel dalam penelitian ini sebanyak 30 orang yang diambil dengan teknik pengambilan sampel menggunakan total sampling. Pengumpulan data dilakukan dengan wawancara dan pengisian kuesioner. Data yang diperoleh dianalisis secara univariat.

\section{HASIL DAN PEMBAHASAN}

Tabel 1 Karakteristik Responden

\begin{tabular}{cccccc}
\hline Karakter & Kategori & \multicolumn{2}{c}{ Karu } & \multicolumn{2}{c}{ Katim } \\
istik & & n & $\%$ & n & $\%$ \\
\hline Umur & Dewasa & 1 & 10 & 3 & 15 \\
& Awal & & & &
\end{tabular}




\begin{tabular}{|c|c|c|c|c|c|c|c|c|c|c|}
\hline & \multirow{2}{*}{$\begin{array}{c}\text { Dewasa } \\
\text { Akhir } \\
\text { Lansia } \\
\text { Awal }\end{array}$} & \multirow[t]{2}{*}{7} & 70 & 15 & \multicolumn{2}{|c|}{75 No Kategori } & \multicolumn{4}{|c|}{ Pernyataan } \\
\hline & & & 20 & 2 & 10 & & $\begin{array}{l}\text { Pendekatan } \\
\text { Manajemen }\end{array}$ & $\begin{array}{c}\text { Kompensasi } \\
\text { dan } \\
\text { Penghargaan }\end{array}$ & $\begin{array}{l}\text { Hubungan } \\
\text { Profesional }\end{array}$ & $\begin{array}{c}\text { Pemberian } \\
\text { Asuhan } \\
\text { Keperawatan }\end{array}$ \\
\hline Jenis & Laki-laki & 1 & 10 & 5 & 25 & & $\%$ & n $\%$ & $\%$ & n $\%$ \\
\hline Kelamin & Perempua & 9 & 90 & 15 & 757 & Baik & 50 & 90 & 80 & 60 \\
\hline end & Voke & & & 16 & 80 & $\begin{array}{l}\text { Kurang } \\
\text { Baik }\end{array}$ & 50 & 10 & 20 & 40 \\
\hline an & Profesi & 1 & 70 & 4 & 20 & Total & 100 & 100 & $\begin{array}{ll}10 & 100\end{array}$ & 100 \\
\hline
\end{tabular}

\begin{tabular}{lccccc}
\hline Lama & Lama & 5 & 50 & 8 & 40 \\
Kerja & Baru & 5 & 50 & 12 & 60 \\
\hline
\end{tabular}

Tabel 3 Gambaran kinerja kepala

Hasil penelitian menunjukkan bahwa sebagian besar kepala ruangan memiliki umur kategori dewasa akhir sebanyak 7 (70\%) responden, berjenis kelamin perempuan sebanyak 9 (90\%) responden, memiliki pendidikan profesi sebanyak 7 (70\%) responden dan seluruh kepala ruangan lama bekerja ( $\geq 10$ tahun) sebanyak 5 (50\%) responden. Hasil penelitian juga menunjukkan sebagian besar ketua tim memiliki umur kategori dewasa akhir sebanyak 15 (75\%) responden, berjenis kelamin perempuan sebanyak 15 (75\%) responden, memiliki pendidikan vokasi sebanyak 11 (55\%) responden dan seluruh ketua tim baru bekerja (< 10 tahun) sebanyak 12 $(60 \%)$ responden.

\section{Tabel 2 Distribusi Frekuensi Berdasarkan Kuesioner Kinerja Kepala \\ Ruangan $(n=10)$}

\begin{tabular}{ccc}
\hline $\begin{array}{c}\text { Kinerja Kepala } \\
\text { Ruangan }\end{array}$ & $\begin{array}{c}\text { Jumlah } \\
\text { Responde } \\
\text { n }\end{array}$ & $\begin{array}{c}\text { Persentas } \\
\text { e (\%) }\end{array}$ \\
\hline Baik & 5 & 50 \\
Kurang Baik & 5 & 50 \\
\hline Jumlah & 10 & 100.0 \\
\hline
\end{tabular}

Hasil penelitian menunjukkan bahwa kepala ruangan memiliki kinerja yang baik dan kurang baik masing-masing sebanyak 5 (50\%) responden.

\section{Tabel 4 Distribusi Frekuensi \\ Berdasarkan Kuesioner Kinerja ketua tim

$$
(n=20)
$$

\begin{tabular}{|c|c|c|c|c|}
\hline \multirow[t]{3}{*}{ No Kategori } & \multicolumn{4}{|c|}{ Pernyataan } \\
\hline & $\begin{array}{l}\text { Pendekatan } \\
\text { Manajemen }\end{array}$ & $\begin{array}{c}\text { Kompensasi } \\
\text { dan } \\
\text { Penghargaan }\end{array}$ & $\begin{array}{l}\text { Hubungan } \\
\text { Profesional }\end{array}$ & $\begin{array}{c}\text { Pemberian } \\
\text { Asuhan } \\
\text { Keperamatan }\end{array}$ \\
\hline & $\mathrm{n}$ & $\%$ & $\%$ & $\%$ \\
\hline 1 Baik & 10 & 90 & 90 & 11 \\
\hline $2 \begin{array}{l}\text { Kurang } \\
\text { Baik }\end{array}$ & 10 & 10 & 10 & 45 \\
\hline Total & $20 \quad 100$ & 100 & $20 \quad 100$ & $20 \quad 100$ \\
\hline
\end{tabular}


Tabel 5 Gambaran kinerja ketua tim $(n=20)$

\begin{tabular}{ccc}
\hline $\begin{array}{c}\text { Kinerja Ketua } \\
\text { Tim }\end{array}$ & $\begin{array}{c}\text { Jumlah } \\
\text { Responden }\end{array}$ & $\begin{array}{c}\text { Persentase } \\
\text { (\%) }\end{array}$ \\
\hline Baik & 10 & 50 \\
Kurang Baik & 10 & 50 \\
\hline Jumlah & 20 & 100.0 \\
\hline
\end{tabular}

Hasil penelitian menunjukkan bahwa ketua tim memiliki kinerja yang baik dan kurang baik masing-masing sebanyak $10(50 \%)$ responden.

\section{PEMBAHASAN}

Gambaran karakteristik kepala ruangan dan katim (umur, jenis kelamin, pendidikan dan lama kerja) di Ruang Model Praktik Keperawatan Profesional (MPKP) Rumah Sakit Jiwa Daerah Provinsi Jambi Tahun 2020

1. Umur

Berdasarkan penelitian karakteristik umur kepala ruangan di Ruang Model Praktik Keperawatan Profesional (MPKP) Rumah Sakit Jiwa Daerah Provinsi Jambi Tahun 2020 diketahui bahwa sebagian besar kepala ruangan memiliki umur kategori dewasa akhir sebanyak 7 (70\%) responden. Sebagian besar ketua tim memiliki umur kategori dewasa akhir sebanyak 15 (75\%) responden.

Hasil penelitian yang dilakukan oleh (Weliya, 2018) menunjukkan bahwa sebagian besar responden memiliki umur 21-30 tahun (66,7\%). Sedangkan penelitian oleh Rahayu (2017) menunjukkan bahwa rerata umur 41,11 tahun (SD 4,837).

Umur sebagai salah satu sifat karakteristik tentang orang yang dalam studi epidemiologi merupakan variable yang cukup penting karena cukup banyak penyakit ditemukan dengan berbagai variasi frekuensi yang disebabkan oleh umur. Umur merupakan salah satu sifat karakteristik tentang orang yang sangat utama karena umur mempunyai hubungan yang erat dengan keterpaparan (Noor, 2012).

Menurut asumsi peneliti, kepala ruangan dan ketua tim di ruang MPKP memiliki umur dalam kategori dewasa akhir (36-45 tahun). Hal ini menunjukkan baik karu dan katim memiliki pengalaman yang lebih banyak jika dilihat dari usia karena semakin maka semakin tinggi umur seseorang kedewasaan teknis dan psikologisnya juga semakin tinggi.

2. Jenis Kelamin

Berdasarkan penelitian karakteristik jenis kelamin kepala ruangan di Ruang Model Praktik Keperawatan Profesional (MPKP) Rumah Sakit Jiwa Daerah Provinsi Jambi Tahun 2020 diketahui bahwa sebagian besar kepala ruangan berjenis kelamin perempuan sebanyak 9 (90\%) responden dan sebagian besar ketua tim berjenis kelamin perempuan sebanyak 15 (75\%) responden.

Hasil penelitian yang dilakukan oleh (Weliya, 2018) menunjukkan bahwa sebagian besar responden adalah perempuan (54,5\%). Penelitian oleh Rumayar (2016) menunjukkan dari 40 responden yang berjenis kelamin wanita lebih banyak yaitu sebesar 65,2\%. Jenis kelamin merupakan salah satu variabel deskriptif yang 
dapat memberikan perbedaan angka/ rate kejadian pada pria dan wanita. Dalam hal perbedaan kejadian penyakit pada perbedaan jenis kelamin harus dipertimbangkan pula berbagai variabel lain seperti umur atau variabel lainnya yang mempunyai perbedaan penyebaran menurut jenis kelamin. Perbedaan insiden penyakit menurut jenis kelamin, dapat timbul karena bentuk anatomis, fisiologis, dan system hormonal yang berbeda (Noor, 2012).

Menurut asumsi peneliti, kepala ruangan ketua tim di ruang MPKP sebagian besar adalah perempuan. Hal ini mungkin dikarenakan dalam dunia keperawatan lebih identik dengan wanita. Selain itu, jenis kelamin perempuan cenderung memiliki sifat yang lebih sabar dan berpikir secara kritis ketika akan melakukan sesuatu. Sesuai dengan hasil penelitian (Setyaningsih, 2013) yang mengatakan bahwa para wanita lebih bersedia menyesuaikan diri terhadap otoritas dan pria lebih agresif serta lebih memiliki pengharapan yang lebih, perempuan cenderung lebih mampu menjadi pendengar yang baik, langsung menangkap fokus diskusi dan tidak selalu berfokus pada diri sendiri.

3. Pendidikan

Berdasarkan penelitian karakteristik pendidikan kepala ruangan di Ruang Model Praktik Keperawatan Profesional (MPKP) Rumah Sakit Jiwa Daerah Provinsi Jambi Tahun 2020 diketahui bahwa sebagian besar kepala ruangan memiliki pendidikan profesi

(Strata
+ Profesi Keperawatan) sebanyak 7 (70\%) responden dan sebagian besar ketua tim memiliki pendidikan Vokasi (Diploma III dan Strata I) sebanyak 11 (55\%) responden.

Hasil penelitian yang dilakukan oleh (Weliya, 2018) menunjukkan bahwa sebagian besar responden memiliki tingkat pendidikan S1 (51,5\%). Penelitian yang dilakukan Rahayu (2017) menunjukkan bahwa karakteristik pendidikan karu dan katim terbanyak pendidikan D4 Keperawatan (72,2\%).

Pendidikan adalah proses perubahan sikap dan tata laku seseorang atau kelompok orang dalam usaha mendewasakan manusia melalui upaya pengajaran dan pelatihan. Tingkatan pendidikan terbagi menjadi tiga yaitu pendidikan dasar berbentuk sekolah dasar (SD), dan Madrasah Ibtidaiyah serta Sekolah Menengah Pertama (SMP) atau Madrasah Tsanawiyah (MTS) atau bentuk lain yang sederajat. Pendidikan menengah berbentuk Sekolah Menengah Atas (SMA), Madrasah Aliyah (MA), Sekolah Menengah Kejuruan (SMK) dan bentuk lain sederajat. Pendidikan tinggi berbentuk pendidikan diploma, sarjana, magister dan doktor (Priyoto, 2014).

Menurut asumsi peneliti, kepala ruangan di ruang MPKP sebagian besar memiliki pendidikan Strata I (Nerss), sedangkan sebagian besar ketua tim memiliki pendidikan Diploma III. Perawat yang memiliki pendidikan tinggi dapat dikatakan memiliki peluang kinerja yang baik. Hal ini dikarenakan, semakin 
tinggi pendidikan seseorang maka semakin banyak ilmu dan informasi yang diperoleh selama menempuh pendidikan.

4. Lama Kerja

Berdasarkan penelitian karakteristik lama kerja, kepala ruangan di Ruang Model Praktik Keperawatan Profesional (MPKP) Rumah Sakit Jiwa Daerah Provinsi Jambi Tahun 2020 diketahui bahwa kepala ruangan ada yang baru bekerja (< 10 tahun) dan telah lama bekerja ( $\geq 10$ tahun) masing-masing sebanyak 5 (50\%) responden. Sedangkan sebagian besar ketua tim baru bekerja $(<10$ tahun) sebanyak $12 \quad(60 \%)$ responden.

Hasil penelitian yang dilakukan oleh Rumayar (2016) menunjukkan dari 40 responden yang memiliki masa kerja kurang dari 10 tahun sebanyak 28 responden sedangkan responden yang memiliki masa kerja di atas 10 tahun berjumlah 52 responden. Penelitian yang dilakukan (Rahayu, 2017) menunjukkan bahwa karu dan katim rerata lama bekerja 16,44 tahun (SD 4,462).

Lama kerja adalah jangka waktu atau lamanya seseorang bekerja pada suatu instansi, kantor, dan sebagainya. Lama kerja juga merupakan fakor yang bekaitan dengan lamanya seseorang bekerja di suatu tempat. Lama kerja juga merupakan jangka waktu seseorang yang sudah bekerja dari pertama mulai masuk hingga bekerja (Noor, 2012).

Menurut asumsi peneliti, kepala ruangan di ruang MPKP masing-masing ada yang baru bekerja dan telah lama bekerja. Sedangkan sebagian besar ketua tim baru bekerja ( $<10$ tahun). Karakteristik lama kerja di atas menunjukkan bahwa baik kepala ruangan dan ketua tim telah siap untuk menjalankan tugas sebagai pimpinan. Kepala ruangan dengan lama kerja yang lebih dari 10 tahun, maka pengalaman dan keterampilannya juga meningkat, kepala ruangan dan ketua tim dapat dikatakan telah banyak melakukan tindakan medik selama menjalankan tugas di rumah sakit jiwa daerah provinsi Jambi. Karakteristik lama bekerja tersebut juga menggambarkan bahwa baik kepala ruangan dan ketua tim dapat dengan mudah memahami dan menerapkan MPKP di setiap ruang masing-masing dengan menerima informasi serta pelatihan tentang penerapan 4 pilar MPKP.

Gambaran kinerja kepala ruangan di Ruang Model Praktik Keperawatan Profesional (MPKP) Rumah Sakit Jiwa Daerah Provinsi Jambi Tahun 2020

Berdasarkan penilaian kinerja kepala ruangan di Ruang Model Praktik Keperawatan Profesional (MPKP) Rumah Sakit Jiwa Daerah Provinsi Jambi Tahun 2020 diketahui bahwa kepala ruangan memiliki kinerja yang baik dan kurang baik masing-masing sebanyak 5 (50\%) responden.

Hasil penelitian menunjukkan bahwa kinerja kepala ruangan di Ruang MPKP belum dilakukan secara optimal. Hal ini dikarenakan ada sebagian kepala ruangan yang belum menerapkan seluruh 4 pilar MPKP. Sedangkan sebagian lainnya telah melaksanakan 4 pilar MPKP yang dilihat dari hasil pengisian kuesioner yang telah dilakukan.

Hasil penelitian kinerja kepala ruangan di ruang MPKP dapat dilihat 
dari hasil data yang menunjukkan pada bagian perencanaan sebanyak $30 \%$ karu tidak mengerjakan filosofi, pada bagian pengarahan, $50-70 \%$ sering melakukan iklim motivasi dan pendelegasian, sedangkan 40-60\% kadang-kadang dan 10\% karu tidak melakukan supervisi. Pada bagian pengendalian, 20-60\% audit dokumentasi tidak dikerjakan, 20-70\% survei kepuasan tidak dikerjakan, 10\% case conference tidak dikerjakan dan 40\% pemberian asuhan keperawatan yang tidak dikerjakan kecuali pada pasien halusinasi dan defisit perawatan diri. Hal ini menunjukkan bahwa penerapan 4 pilar MPKP belum dilaksanakan secara optimal baik diruang MPKP Pemula, Transisi dan Profesional. Kepala ruangan dengan kinerja baik didukung dari hasil karakteristik responden dimana sebagian besar kepala ruangan memiliki usia dewasa akhir, jenis kelamin perempuan, pendidikan strata I dan telah lama bekerja sehingga memiliki pengalaman yang banyak dalam pemberian tindakan keperawatan di rumah sakit.

Penelitian yang dilakukan (Wahyuni, 2007) menunjukkan bahwa tingkat kompetensi Kepala Ruang dalam pelaksanaan Standar Manajemen Pelayanan Keperawatan masih rendah (antara 48,5 s/d 66,7). Hanya sebagian Kepala Ruang yang mengetahui tentang rencana pengembangan Rumah Sakit, tidak ada yang menyusun perencanaan berdasarkan data klinis dan kinerja pelayanan.

Penelitian yang dilakukan (Rahayu, 2017) menunjukkan bahwa kemampuan karu dan katim dalam penerapan MPKP rata-rata secara keseluruhan adalah $72,30 \%$, dengan rata-rata pada pendekatan manajemen adalah $72,42 \%$, kompensasi dan penghargaan 59,38\%, hubungan profesional 75,29\%, dan asuhan keperawatan pada pasien halusinasi $82,07 \%$.

Penilaian atau evaluasi kinerja di ruang MPKP ditujukan pada kepala ruangan, Katim dan perawat pelaksana. Kemampuan tiap SDM dievaluasi dengan menggunakan supervisi baik secara langsung (observasi) maupun tidak langsung (melalui dokumentasi). Kinerja kepala ruangan dievaluasi oleh Kepala Bidang Keperawatan dan Konsultan (Keliat, Model Praktik Keperawatan Profesional Jiwa, 2015).

Kinerja adalah hasil evaluasi terhadap pekerjaan yang telah dilakukan dibandingkan dengan kriteria yang telah ditetapkan bersama. Kinerja merupakan cara perseorangan atau kelompok dari suatu organisasi menyelesaikan suatu pekerjaan atau tugas (Rismawati, 2011). Evaluasi kinerja dimaksudkan sebagai umpan balik kepada karyawan mengenai pandangan organisasi terhadap kinerja karyawan, sebagai dasar untuk alokasi ganjaran (upah) dan menetapkan keputusan (Rivai \& Mulyadi, 2010).

Adapun kinerja kepala ruangan dalam 4 pilar MPKP terdiri dari pendekatan manajemen (perencanaan, pengorganisasian, pengarahan dan pengendalian), kompensasi dan penghargaan (evaluasi kinerja perawat dan pengembangan perawat). Hubungan profesional (rapat keperawatan, case conference, rapat tim kesehatan dan visit dokter) dan pemberian asuhan keperawatan (Keliat, Model Praktik Keperawatan Profesional Jiwa, 2015).

Menurut asumsi peneliti, kepala ruangan di ruang MPKP perlu diberikan pelatihan dan diklat serta penilaian kinerja untuk lebih memahami apa 
saja yang harus dikerjakan serta penerapan 4 pilar MPKP yang optimal dan melakukan evaluasi kinerja dari pelaksanaan MPKP sehingga menjadi acuan bagi ketua tim dan perawat pelaksana di ruang MPKP tersebut. Kepala ruangan dengan kinerja baik adalah kepala ruangan Srikandi, Omega, Pega, Arjuna dan Yudistira. Sedangkan kepala ruangan Epsilon, Delta, Arimbi, Gama dan Beta memiliki kinerja yang kurang baik.

\section{Gambaran kinerja ketua tim di Ruang Model Praktik Keperawatan Profesional (MPKP) Rumah Sak it Jiwa Daerah Provinsi Jambi Tahun 2020}

Berdasarkan penilaian kinerja ketua tim di Ruang Model Praktik Keperawatan Profesional (MPKP) Rumah Sakit Jiwa Daerah Provinsi Jambi Tahun 2020 diketahui bahwa ketua tim memiliki kinerja yang baik dan kurang baik masing-masing sebanyak 10 (50\%) responden.

Hasil penelitian menunjukkan bahwa kinerja ketua tim di Ruang MPKP belum secara maksimal. Hal ini dikarenakan ada sebagian ketua tim belum menerapkan seluruh 4 pilar MPKP atau tidak melaksanakan beberapa kegiatan dari 4 pilar tersebut. Sedangkan sebagian ketua tim lainnya telah melaksanakan 4 pilar MPKP yang dilihat dari hasil pengisian kuesioner yang telah dilakukan.

Hasil penelitian kinerja ketua tim di ruang MPKP juga dapat dilihat dari hasil observasi yang menunjukkan pada pilar pengarahan bagian postconference sebanyak 30\% tidak dikerjakan, 10-30\% iklim motivasi kadang-kadang dilakukan, 50\% pendelegasian sering dilakukan dan $30-45 \%$ supervisi kadang-kadang dilakukan. Pada pilar kompensasi dan penghargaan bagian evaluasi kinerja perawat pelaksanan $10 \%$ tidak dikerjakan, $10 \%$ case conference tidak dikerjakan dan $45 \%$ pemberian asuhan keperawatan yang tidak dikerjakan kecuali pada pasien halusinasi dan defisit perawatan diri. Hal ini menunjukkan bahwa penerapan 4 pilar MPKP belum dilaksanakan secara optimal karena tidak keseluruhan dikerjakan oleh ketua tim. Ketua tim sebagian besar kinerja tidak baik dikarenakan sebagian besar kepala ruangan memiliki usia dewasa akhir, jenis kelamin perempuan, pendidikan diploma III dan sebagian baru bekerja sehingga memiliki pengalaman yang kurang dalam pemberian tindakan di rumah sakit.

Hasil penelitian ini sejalan dengan penelitian (Mulyaningsih, 2013) berdasarkan hasil audit asuhan keperawatan di salah satu ruangan RSJD Surakarta didapatkan nilai ratarata $85 \%$ (baik). Nilai dokumentasi yang paling rendah terdapat pada evaluasi (50\%). Hal ini menunjukkan bahwa kinerja perawat masih kurang.

Hasil penelitian ini juga didukung oleh penelitian (Hartanto, 2013) menunjukkan bahwa kinerja perawat pelaksana secara umum termasuk dalam kategori kinerja yang sedang dengan presentasi $88,47 \%$ dari batas tinggi nilai kategori sedang. secara berurutan dari hasil penelitian tersebut yaitu tanggung jawab, pendokumentasian dan disiplin.

Penelitian yang dilakukan oleh (Weliya, 2018) menunjukkan bahwa pada semua indikator MPKP sebagian besar dapat dikategorikan baik. Pada aspek kinerja perawat diperoleh hasil bahwa $66,7 \%(N=22)$ memiliki persepsi kinerja yang baik dan sebesar $33,3 \%(N=11)$ memiliki persepsi kinerja cukup baik.

Penilaian kinerja katim dievaluasi oleh Kepala Bidang 
Keperawatan, Konsultan dan kepala ruangan. Kinerja adalah gambaran pencapaian pelaksanaan (achievement) suatu program kegiatan perencanaan strategis dan operasional organisasi (efforts) oleh seseorang atau sekelompok orang dalam suatu organisasi baik secara kuantitas dan kualitas, sesuai dengan kewenangan dan tugas tanggung jawabnya, legal dan tidak melanggar hukum, etika dan moral. Kinerja sendiri merupakan penjabaran visi, misi, tujuan dan strategi organisasi (Nursalam, 2015).

Adapun kinerja ketua tim dalam 4 pilar yaitu pendekatan manajemen (perencanaan, pengorganisasian dan pengarahan), kompensasi dan penghargaan (evaluasi kinerja perawat), hubungan profesional (case conference dan visit dokter) dan pemberian asuhan keperawatan (Keliat, Model Praktik Keperawatan Profesional Jiwa , 2014).

Menurut asumsi peneliti, hasil penelitian ini menunjukkan bahwa ketua tim di ruang MPKP memerlukan pembelajaran dan pengawasan serta evaluasi kinerja dalam penerapan 4 pilar MPKP tersebut. Hal ini dilakukan untuk memperbaiki kinerja ketua tim yang tidak mengerjakan 4 pilar MPKP secara keseluruhan. Selain itu, ketua tim perlu mendapat pelatihan dan diklat agar lebih memahami 4 pilar MPKP tersebut. 10 katim dengan kinerja yang baik adalah 2 katim ruang Delta, 1 katim ruang Epsilon, 1 katim Omega, 2 katim Beta, 1 katim Pega, 1 katim Srikandi, 1 katim Arjuna dan 1 katim Yudistira.

\section{KESIMPULAN}

Hasil penelitian didapatkan bahwa kepala ruangan memiliki umur kategori dewasa akhir sebanyak 7 (70\%) responden, berjenis kelamin perempuan sebanyak 9 (90\%) responden, memiliki pendidikan profesi (Strata I + Profesi Keperawatan) sebanyak 7 (70\%) responden dan seluruh kepala ruangan telah lama bekerja ( $\geq 10$ tahun) sebanyak 5 (50\%) responden. Sedangkan sebagian besar ketua tim memiliki umur kategori dewasa akhir sebanyak 15 (75\%) responden, berjenis kelamin perempuan sebanyak 15 (75\%) responden, memiliki pendidikan vokasi (Diploma III dan Strata I) sebanyak 11 (55\%) responden dan seluruh ketua tim telah lama bekerja (< 10 tahun) sebanyak $12 \quad(60 \%)$ responden. Kepala ruangan memiliki kinerja yang baik dan kurang baik masing-masing sebanyak 5 (50\%) responden. Ketua tim memiliki kinerja yang baik dan kurang baik masingmasing sebanyak $10(50 \%)$ responden.

\section{DAFTAR PUSTAKA}

Hartanto, B. (2013). Motivasi Kinerja Perawat Dalam Pelaksanaan Model Praktik Keperawatan Profesional. Jendela Nursing Journal, Vol 2 No 1, 1-9.

Keliat, B. (2014). Model Praktik Keperawatan Profesional Jiwa. Jakarta: EGC.

Keliat, B. (2015). Model Praktik Keperawatan Profesional Jiwa. Jakarta: EGC.

Kemenkes RI. (2011). Kesehatan Jiwa Secara Global . Jakarta: Departemen Kesehatan Republik Indonesia.

Mulyaningsih. (2013). Peningkatan Kinerja Perawat Dalam Penerapan MPKP dengan Supervisi Oleh Kepala Ruang di RSJD Surakarta. Gaster, Vol 10 No 1, 1-8.

Murwani, \& Herlambang. (2012). Cara Mudah Memahami Manajemen Kesehatan dan Rumah Sakit. Yogyakarta: Goysen Publishing. 
Noor. (2012). Epidemiologi. Jakarta: Rineka Cipta.

Nursalam. (2015). Manajemen Keperawatan. Jakarta: Salemba Medika.

Priyoto. (2014). Teori Sikap dan Perilaku Dalam Kesehatan. Yogyakarta: Nuha Medika.

Rahayu, P. (2017). Hubungan Kemampuan Karu dan Katim Dalam Penerapan MPKP Jiwa dengan Hasil Asuhan Keperawatan Pada Pasien Halusinasi. Jurnal Keperawatan, Vol 5 No 1, 1-9.

Rismawati. (2011). Evaluasi Kinerja (Penilaian Kinerja Atas Dasar Prestasi Kerja Berorientasi Ke depan). Bandung: Celebes Media Perkasa.

Rivai, V., \& Mulyadi, D. (2010). Kepemimpinan dan Perilaku Organisasi. Jakarta: PT Raja Grafindo Persada.
Setyaningsih, Y. (2013). Hubungan Motivasi dengan Kinerja Perawat di Ruang Rawat Inap RSUD Ungaran. Skripsi, 1-9.

Sitorus, R. (2014). Model Praktik Keperawatan Profesional di Rumah Sakit Penataan Struktur \& Proses (Sistem) Pemberian Asuhan Keperawatan di Ruang Rawat. Jakarta: EGC.

Wahyuni, S. (2007). Analisis Kompetensi Kepala Ruang Dalam Melaksanakan Standar Manajemen Pelayanan Keperawatan di Instalasi Rawat Inap RSUD Banjarnegara. Tesis, 1-28.

Weliya, F. (2018). Gambaran Mengenai Pelaksanaan Model Praktik Keperawatan Profesional di Rumah Sakit Dr. Moewardi Surakarta. Naskah Publikasi, 1-10. 